\section{Géneros}

Multidisciplinary Journal of Gender: Studies

\section{Hipatia Press \\ www.hipatiapress.com}

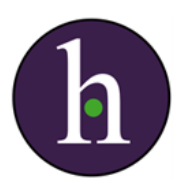

Instructions for authors, subscriptions and further details:

http://generos.hipatiapress.com

\title{
Influence of Perceived Glass Ceiling and Personal Attributes on Female Employees' Organizational Commitment
}

Chibuzor Uchenna Onuoha ${ }^{1,2}$

Erhabor Sunday Idemudia ${ }^{1}$

1) North West University. South Africa

2) Adekunle Ajasin University. Nigeria.

Date of publication: February $25^{\text {th }}, 2018$

Edition period: February 2018 - June 2018

To cite this article: Onuoha, Ch. U. \& Idemudia, E. S. (2018). Influence of Perceived Glass Ceiling and Personal Attributes on Female Employees' Organizational Commitment. Multidisciplinary Journal of Gender Studies, 7(1), 1556-1578. doi: 10.4471/generos.2018.3052

To link this article: http://dx.doi.org/10.4471/generos.2018.3052

\section{PLEASE SCROLL DOWN FOR ARTICLE}

The terms and conditions of use are related to the Open Journal System and

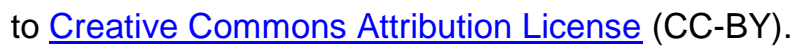




\section{Influence of Perceived Glass Ceiling and Personal Attributes on Female Employees' Organizational Commitment}

Chibuzor Uchenna Onuoha

Noth West University
Erhabor Sunday Idemudia

Noth West University

\section{Abstract}

The present study, which was designed as a cross-sectional research investigated the role of personal attributes (age, education, job position, organizational tenure) and the perceived glass ceiling on organizational commitment of senior level female employees in public sector organizations. One hundred and fifty-two female workers with a mean age of 36.6 (s.d. = 9.03) were conveniently sampled from eight public sector organizations in southwest Nigeria. Job position was categorized into three: supervisor $(33.6 \%)$, middle management $(51.3 \%)$ and senior management $(15.1 \%)$. Their educational status ranged from national diploma to post-graduate certificates. Each respondent completed a questionnaire that contained standardized scales that measured perceived glass ceiling, organizational commitment, age, education, job position and organizational tenure. Results showed significant joint influence of age, education, job position, organizational tenure and perceived glass ceiling on organizational commitment. Perceived glass ceiling and age contributed most to organizational commitment. It was concluded that personal attributes influenced organizational commitment but perceived glass ceiling and age contributed significantly to organizational commitment.

Keywords: perceived glass ceiling, organizational commitment, public sector organizations 


\section{Influencia del Techo de Cristal Percibido y los Atributos Personales en el Compromiso Organizacional de las Empleadas}

Chibuzor Uchenna Onuoha

Noth West University
Erhabor Sunday Idemudia

Noth West University

\section{Resumen}

El presente estudio transversal investigó el papel jugado por variables sociodemográficas tales como edad, nivel educativo, cargo o permanencia en la organización en el techo de cristal percibido sobre el compromiso organizacional de empleadas de alto nivel en organizaciones del sector público. Ciento cincuenta y dos trabajadoras con una edad media de 36.6 (d.s.=9.03) pertenecientes a ocho organizaciones del sector público en el suroeste de Nigeria participaron de esta investigación. La posición laboral se clasificó en tres: supervisora (33.6\%), mando intermedio (51.3\%) y alta directiva (15.1\%). El nivel educativo varió de diplomada a estudios de posgrado. Cada encuestada completó un cuestionario con escalas estandarizadas para medir el techo de vidrio percibido, el compromiso organizacional, la edad, el nivel educativo, el cargo y la permanencia en la organización. Los resultados muestran una influencia conjunta significativa de la edad, el nivel educativo, el puesto de trabajo, la permanencia en la organización y el techo de cristal percibido sobre el compromiso organizacional; siendo el techo de vidrio percibido y la edad las variables que más contribuyen al compromiso organizacional.

Palabras clave: techo de vidrio percibido, compromiso organizacional, organizaciones del sector público 
large body of cross-national research have examined gender influence in organizational commitment (Aydin, Sarier, \& Sengul. 2011; Dalgic, 2014; Downes, Hemmasi, \& Eshghi, 2014; Kumasey, Delle, \& Ofei, 2014; Macdonald \& Levy, 2016; Obeng \& Ugboro, 2017; Voloshin, 2016). The findings contributed immensely to the understanding of the role gender play in organizational commitment. In Nigeria, gender influence in organizational commitment has been investigated with participants comprised of a mixed gender sample (Adenguga, Adenuga, \& Ayodele, 2013; Akinyemi, 2014; Ajayi, 2017; Ogba, 2008). However, conclusions of most of these past studies were not focused on understanding personal attribute difference in organizational commitment of the same sex sample. Also, identifying the likely psychological factors that might influence organizational commitment of the same sex employees in Nigeria is understudied.

Organizational commitment is an established work-related attitude for measuring the correspondence between an employee and the organization. It is a psychological state that assesses the strength of an employee's desire, need and obligation to maintain membership with an organization (Meyer \& Allen, 1991). A highly committed employee is characterized as an individual who is willing to go the extra mile for the organization, maintain affiliation with it, and identify with its goals and values (Meyer \& Allen, 1991; Meyer, Kam, Goldenberg \& Bremner, 2013; Steers, 1977). Thus, it is assumed that organizational commitment is a major factor that can differentiate highly effective organizations from the less effective ones. Organizational commitment is associated with critical organizational outcomes such as turnover intentions, wellbeing, productivity and organizational performance (Meyer et al., 2013). Taking these outcomes into consideration, it is logical to aver that organizations may value committed employees since they are most likely to contribute the most to organizational effectiveness.

As a personal attribute, age can have a strong influence on an employee's level of organizational commitment. The view is based on findings of anecdotal and empirical fine-grained studies that suggested that age and organizational commitment may be related (Abdul-Nasiru, Mensah, Amponsah-Tawiah, Simpeh, \& Kumasey, 2014; Bal \& Kooji, 2011; De 
Lange, Taris, Jansen, Smulders, Houtman, \& Kompier, 2006; Macdonald \& Levy, 2016; Salami, 2008). Review of past studies in the organizational commitment literature revealed a three-fold age influence on organizational commitment. In one category are findings that showed age had a positive significant relationship with organizational commitment (Affum-Osei, Acquaah, \& Acheampong, 2015; Ferreira \& Coetzee, 2010; Keebler, 2012; Ogba, 2008; The Center on Aging \& Work, 2011), and implied that older workers evinced a higher commitment to the organization. An intuitively appealing explanation for this attitude is that as workers age, access to alternative employment opportunities becomes less and this may elicit stronger emotional attachment to their present organization.

The second category consist of studies with contrary findings in that it was suggested age is negatively related to organizational commitment (e.g., Abrams, Swift, \& Drury, 2016; Bayl-Smith \& Griffin, 2014; Kunze, Boehm, \& Bruch, 2011; Redman \& Snape, 2006). In essence, these findings, which showed that organizational commitment declined among older employees may be an indication of waning emotional attachment to the organization as employees grow older. Physiological changes that result in deteriorating physical and mental fitness occur as an individual cross age 25 (Boersch-Supan, Duezguen, \& Weiss, 2005; Skirbekk, 2008; van Ours, 2009) and may contribute to an employee's negative feeling towards the organization. Lastly are findings that surprisingly showed no significant age influence on organizational commitment (Chui, Tong, \& Mula, 2007; Lumley, 2009). These studies do not support the view that age plays a significant role in organizational commitment, and suggested that any change in commitment is attributable to factors other than age.

Another individual attribute that may play a role in organizational commitment is formal education (Sabahattin, Mehmet, Dilaver, \& Erdem, 2017). Although findings are inconclusive and therefore confusing, some researchers are of the view that the higher an employee's educational status, the lower his/her level of organizational commitment (Adenuga, Adenuga, \& Ayodele, 2013; Sikorska-Simmons; 2004; Martin \& Roodt, 2008; Yew, 2008). The negative relationship may be attributed to more educated employees having a higher expectation of work outcomes (e.g. pay and 
promotion), and when this is not satisfied, the employee disconnects from the organization (Allen \& Meyer, 1991).

On the other hand, Gallie \& White (1993) reported that higher educational level positively influenced task commitment. It is implied from the finding that highly educated employees perceived their jobs as a 'calling' or 'vocation' to which they were committed to advance (Duffy, Bott, Allan, Torrey, \& Dik, 2012). In addition to these preceding views are studies that suggest that there is no relationship between education and organizational commitment (Akinyemi, 2014; Zaitouni \& Sawalha, 2011). What this finding suggests is that formal education, irrespective of the level attained, has no influence on an employee's strength of identification with, or emotional attachment to his organization.

Research is unequivocal that years spent working for a company can influence an employee's level of organizational commitment (Akinyemi, 2014; Obeng \& Ugboro, 2017; Ogunkoya, Elumah, \& Shobayo, 2013). As with other individual attributes, studies that investigated the relationship have been neither equivocal nor definite in their findings. Findings that reported a positive relation (e.g. Meyer, Stanley, Herscovitch, \& Topolnytsky, 2002) may suggest fluidity in level of commitment in the early stage of organizational membership, but this then stabilized with tenure as the employee gained authority and increased in emotional bonding with the organization. This feeling of attachment may account for why long-serving employees have a higher tendency to engage in high performance-related behavior such as in-role and extra-role performances (Ng \& Feldman, 2010).

But in other studies, tenure has been shown to be negatively related to organizational commitment (e.g. Boon \& Safa, 2006). The negative association reported by Boon \& Safa is indicative of an unfavourable attitude towards the organization, probably as a result of perceived unsatisfactory outcomes over the years. Also, the longer an employee retains membership, the less they are able, or willing to accept changes in the organization (Kotzé \& Roodt, 2005). Another stream of studies (e.g. Mathieu \& Zajac, 1990) found a positive, but non-significant correlation between tenure and organizational commitment. While the finding contradicted preceding ones, it however suggested that tenure may not be a strong predictor of organizational commitment, although contributing to it. 


\section{Onuoha \& Idemudia-Perceived Glass Ceiling \&Women Organization Commitment}

Job position is another personal factor that may influence organizational commitment. Employees who occupy position of authority most likely have high value alignment which may significantly impact on their overall effectiveness compared to those in lower levels (Boswell, 2000). Generally, senior level employees are portrayed as being more committed than lower level ones. This may not be unexpected as senior level employees are likely to feel they have a higher stake in the survival of the organization, and are therefore motivated into taking actions that ensure its success ( $\mathrm{Ng} \&$ Feldman, 2010; Oldham \& Cummings, 1996). In addition, studies suggest that felt emotional attachment to the organization is positively associated with performance among employees across levels and job positions (Mayer \& Schoorman, 1992; Moorman, Niehoff, \& Organ, 1993).

Glass ceiling, when used in an organizational context, refers to barriers to career advancement for people of colour, and women especially (Baxter \& Wright 2000). Usually, it is inferred when there is perceived lack of objectivity in procedure that lead a to specific human resource or personnel decision that puts an individual at a disadvantage relative to colleagues of comparable qualification such as education, experience, or skill. Perception of a glass ceiling may influence critical employee outcomes such as organizational commitment. In fact, the finding of a recent study showed that a perceived glass ceiling had a greater effect alone when regressed on organizational commitment than when a mediator variable was included in the relationship (Downes, Hemmasi, \& Eshgh, 2014). It was concluded that the finding confirmed the saliency of the glass ceiling perception on employee organizational commitment. In an apparent confirmation of its influence, Foley (1998) reported a negative association between perceived glass ceiling and important work outcomes listed as advancement expectations, organizational commitment, job satisfaction, and turnover intention.

Ramamoorthy \& Stringer (2017) conducted a study that explored the influence of equity perception on dimensions of organizational commitment in a mixed gender sample. They found that women reported greater affective and normative commitments than men when equity perceptions were higher than when they were lower, among other findings. Similarly, Saleem, Rafiq, Yusaf (2017) reported that a glass ceiling negatively 
impacted productivity of female employees, and implied that it could limit their contribution to organizational effectiveness.

The paradox of the contented working woman (Tolbert \& Moen, 1998) has been used to explain gender differences in work attitude. It explained that men and women attach value to different aspects of the job - women tend to place greater emphasis on co-worker relations, they prioritize work that gives them a sense of accomplishment, and women have a higher likelihood to do self-comparison with other women, or with full-time housewives (Hull, 1999). These differences in work attitudes may strongly influence their level of commitment to the organization.

Clark (1997) reported that women exhibited higher levels of job satisfaction compared to males, even though they earned less and had fewer promotion opportunities relative to their male counterparts. The finding is an indication that women's commitment to the organization may be more intact despite barriers to occupational advancement, and indicated they may be higher on continuance commitment (Lumley, 2009).

Conflicting findings have been reported about the existence of a glass ceiling in workplace. Hilary Devey, chief executive of Pall-Ex delivery network as stating that "the idea of a glass ceiling is myth and an excuse used by women to justify their failing in the business world" (Glennie, 2012). In a related development, Madichie (2009) argued that the glass ceiling is no longer a barrier to women upward advancement in the Nigerian context, adding that it had been shattered in numerous spheres as more women take to entrepreneurship. However, analysis of the number of females holding ministerial appointment in Nigeria between 2010 and 2016, revealed a drop from $21.42 \%$ to $13.89 \%$ (This Day Newspaper, April 23 2016) and suggest that glass ceiling may still be a big issue militating against female participation in leadership positions in organizations in Nigeria. Similarly, the reduction in the number of female high political office holders is thought to be symptomatic of the existence of glass ceiling in Nigeria (Olodo \& Emunemu, 2017).

This study is anchored on Side-bets theory (Becker, 1960). According to Becker, commitment is the tendency to engage in "consistent lines of activity" which develops as a "person finds that his involvement in social organization has, in effect, made side bets for him and thus constrained his future". He argued that these 'side bets' could be lost should the individual 


\section{Onuoha \& Idemudia-Perceived Glass Ceiling \&Women Organization Commitment}

decide to leave the organization. Side bets have been explained to mean priced possessions or anything of high value that would be lost or diminish in value in the event that the individual leaves the organization. It includes occupational status, workplace relationships, organizational supported mortgages, subsidized vacations/medical bills, skills acquired, regular source of income and so on. One perspective of the theory that can be used to explain employee continued organizational membership is the belief that the cost of leaving may be perceived to be too high, and a perceived lack of alternative jobs can heighten fears about leaving. This means that even when a worker feels like leaving, the threat of loss commits the individual to the organization (Meyer \& Allen, 1984).

An exploration of organizational commitment in a homogenous sex sample that vary in psychological and personal attributes may help managers evolve effective strategies to retain a committed employee. Based on the studies reviewed, and Mowday, Porter \& Steers's (1982) suggestion that demographic factors can affect organizational commitment, it is hypothesized in this study that personal attributes (age, organizational tenure, education, job position) and the perceived glass ceiling will significantly predict organizational commitment of female senior level employees in the public sector organizations in Nigeria.

\section{Methodology}

\section{Design and Participants}

The design of the study was a cross-sectional ex post facto survey. The design was considered appropriate for the study since none of the variables were subjected to any form of manipulation by the researchers. Respondents included one hundred and fifty-two $(\mathrm{n}=152)$ female employees with a mean age of 36.6 (s.d. = 9.03). Each respondent was given a study questionnaire which they completed and submitted at an agreed collation point. Descriptive statistics indicated an uneven distribution of respondents across job position: Supervisor (51 or 33.6\%), middle management staff ( 78 or $51.3 \%$ ), senior management staff ( 23 or $15.1 \%)$ respectively. There were wide differences in educational status: graduates (76 or 50\%); postgraduate diploma/degree (27 or 15.8\%), 
completed national diploma (36 or $23.7 \%$ ), while only $13(8.6 \%$ ) had senior secondary school certificate. Similarly, percentage distribution across marital status showed the following: married (57.9\%), single (28.6\%), divorced $(4.5 \%)$, separated $(4.5 \%)$ and widowed $(4.5 \%)$. Comparison of respondents organizational tenure showed that the majority (80 or $52.7 \%$ ) had put in less than 10years, 59 (38.8\%) more than 10years but less than 15 years, while $13(8.5 \%)$ had served more than 15 years.

\section{Instrument}

The researchers made use of a carefully constructed questionnaire that contained standardized scales for data collection. The demographic section of the questionnaire was included in order to describe the respondents as accurately as possible. Responses elicited related to respondents' age, job position, highest educational qualification, marital status and organizational tenure.

Perceived glass ceiling was measured with Managerial Attitudes Towards Women Executives Scale (MATWES; Dubno, Costas, Cannon, Wankel, \& Emin, 1979). The MATWES is a 38-item scale written in short lucid narratives, carefully worded to elicit responses on perceived barriers or obstacles to advancement from the perspective of career women who hold executive positions in their organizations. Responses were rated on a 5-point Likert scale with responses that ranged from highly agree (1) to highly disagree (5). A mean score was obtained for the items and scores were interpreted such that a score higher than the mean indicated a high perception of a glass ceiling, while scores lower than the mean indicated a low perception of a glass ceiling. In addition, scores on the MATWES were used to infer negative attitudes towards female employees in managerial positions in their organization (Everett, Thorne \& Danehower, 1996). The Cronbach Alpha of the scale is .88 in the present study. The scale gave acceptable Cronbach Alpha in a pilot study.

Organizational commitment was measured with Allen \& Meyer's (1990), 24-item organizational commitment scale. It is a 3-component scale that measured affective, continuance and normative commitment. In the original scale, items were rated on a 7-point Likert scale with responses that ranged from strongly disagree (1) to strongly agree (7). But in this study, responses were adapted to 5-point Likert scale response in order to 


\section{Onuoha \& Idemudia-Perceived Glass Ceiling \&Women Organization Commitment}

minimize respondents' risk to engage in 'satisficing response style' (Krosnick, 1999). Apparently to control for response bias, the authors included ten items that were negatively phrased and reverse-scored. These were items No: 4, 5, 6, 8,9,12,14,18,19 and 24. Although the utility of negatively worded items in research is a subject of scholarly debate, a counter-argument applauding the strategy as a means to improve the validity of research questionnaires is acknowledged (Baumgartner \& Steenkamp, 2001). A sample item in the scale is: "things were better in the days when people stayed with one organization for most of their careers". The scale has been widely used across cultures and has been evaluated for validity. The Cronbach Alpha of .72 was established for the scale in this study.

\section{Procedure}

Ethical approval. Ethical approval for the study was granted by the Research and Ethics Committee of the Department of Psychology, Adekunle Ajasin University, Ondo State. The researchers got verbal consent from participants on a one-on-one basis after they agreed they understood the purpose of the study. In accordance with the guideline provided by Strydom (2002), the participants were informed they had the right to withdraw at any point they felt uncomfortable continuing in the study.

The researchers obtained permission from the heads of the human resource departments in each of the organizations where the study was conducted. In all, a sample size of 152 female employees was drawn from the population of workers from the organizations. In this study, all-female respondents were chosen because the researchers wanted to employ a relatively homogenous sample with respect to organizational commitment predictors. Although the total number of questionnaires distributed was 250, only 152 copies met the inclusion criteria for coding and further analyses. It took an average of 12 minutes to read, comprehend and respond to all the items in the questionnaire. In determining the sample size, reference was made to the guideline suggested by Sekaran (2003) which stipulated that a sample size of more than 30 and less than 500 from work 
settings was usually sufficient and valid to be analysed using general statistical tools.

Data Analysis. Data collected were analysed using a combination of descriptive (for the demographic variables) and multiple regression analyses to test the influence of age, education, organizational tenure, job position and perceived glass ceiling on organizational commitment. Data was analysed with Statistical Package for Social Sciences (SPSS) version 22.

\section{Results}

\section{Preliminary Analyses}

Preliminary analyses were performed to test for assumptions of normality for the sample. Normality was tested using z-test for skewness and Normal Q-Q plot. The value for Shapiro-Wilk Test was used as numerical means for assessing normality because it is more appropriate for small sample sizes between 50 to 2000 (Tabachnick \& Fidell, 2007). The significance level reported for Shapiro-Wilk test is greater than $0.05(.15)$, and thus normality was assumed. This means that the distribution of organizational commitment did not significantly deviate from normality. Also, the normal Q-Q plot showed adequate normality for organizational commitment.

Table 1

Respondents' socio-demographic characteristics

\begin{tabular}{lll}
\hline Characteristics & Frequency $(\boldsymbol{N})$ & Percentage $(\%)$ \\
\hline Job position & & \\
Supervisor & 51 & 33.6 \\
Middle management & 78 & 51.3 \\
Senior management & 23 & 15.1 \\
Education & & \\
Postgraduate & 27 & 17.76 \\
Graduates & 76 & 50.00 \\
National diploma & 36 & 23.68 \\
Senior secondary school cert & 13 & 8.56 \\
\hline
\end{tabular}


1567 Onuoha \& Idemudia-Perceived Glass Ceiling \&Women Organization Commitment

\section{Organizational tenure}

$<10$ years

80

52.64

$>10$ but less than 15years

59

38.81

More than 15 years

13

8.55

\section{Primary analyses}

Table 2

Correlations among Study Variables

\begin{tabular}{lllllll}
\hline & Age & $\begin{array}{l}\text { Job } \\
\text { position }\end{array}$ & Education & Tenure & $\begin{array}{l}\text { Glass } \\
\text { ceiling }\end{array}$ & $\begin{array}{l}\text { Org } \\
\text { Com }\end{array}$ \\
\hline Age & - & & & & & \\
Job position & $.55^{* *}$ & - & & & & \\
Education & $.38^{* *}$ & $.32^{* *}$ & - & & & \\
Tenure & $.81^{* *}$ & $.49 * *$ & $.34 * *$ & - & & \\
$\begin{array}{l}\text { Perceived } \\
\text { glass ceiling }\end{array}$ & $-.16^{*}$ & -.05 & $.18^{*}$ & -.08 & - & \\
Org Com & $-.18^{*}$ & .01 & $.17^{*}$ & -.04 & $.63^{* *}$ & - \\
\hline$* * p<.01,{ }^{*}<.05$ & & & & & &
\end{tabular}

Results in table 2 showed significant negative correlation between age and organizational commitment, $\mathrm{r}=-.18, \mathrm{p}<.05$. There was a nonsignificant correlation of .01 $(\mathrm{p}=\mathrm{n} . \mathrm{s})$ between job position and organizational commitment. In addition, there was significant positive correlation between education and organizational commitment, $\mathrm{r}=.17, \mathrm{p}<.05$. Tenure was not significantly associated with organizational commitment, $r=-.04$. Finally, perceived glass ceiling and organizational commitment were significantly associated, $\mathrm{r}=.63, \mathrm{p}<.01$.

From the results in table 3 , it is observed that personal attributes and perceived glass ceiling jointly predicted organizational commitment. These factors accounted for $45 \%$ variance of organizational commitment [R2 = $.45, \mathrm{~F}(5,151)=24.04 ; \mathrm{p}<.01]$. The result further showed that among the analyzed predictors, age $[\beta=-.35, \mathrm{t}=-.31, \mathrm{p}<.05]$ and perceived glass ceiling $[\beta=.58, \mathrm{t}=9.01, \mathrm{p}<.01]$ significantly predicted organizational commitment. This indicated that age and perceived glass ceiling were the 
main factors of organizational commitment. Additional analysis of other factors investigated in the study revealed the following results: job position $(\beta=.12, \mathrm{t}=1.60, \mathrm{p}>.05)$, education $(\beta=.10, \mathrm{t}=1.43, \mathrm{p}>.05)$ and organizational tenure $(\beta=.20, \mathrm{t}=1.89, \mathrm{p}>.05)$.

Age $(\beta=-.35, \mathrm{t}=-.31, \mathrm{p}<.05)$ and perceived glass ceiling $(\beta=.58, \mathrm{t}=$ 9.01, $\mathrm{p}<.01)$ significantly influenced organizational commitment with contributions of $35 \%$ and $58 \%$ respectively to the explanation by personal attributes and perceived glass ceiling. Therefore, the hypothesis is partially confirmed.

Table 3

A summary table of multiple regression analysis showing the prediction of organizational commitment by personal attributes and glass ceiling

\begin{tabular}{llllllll}
\hline $\begin{array}{l}\text { Dependent } \\
\text { Variable }\end{array}$ & $\begin{array}{l}\text { Independent } \\
\text { Variables }\end{array}$ & $B$ & $\boldsymbol{T}$ & $\boldsymbol{P}$ & $\boldsymbol{R}^{2}$ & $\boldsymbol{F}$ & $\boldsymbol{P}$ \\
\hline $\begin{array}{l}\text { Organizational } \\
\text { commitment }\end{array}$ & $\begin{array}{l}\text { Age } \\
\text { Job position }\end{array}$ & -.35 & -.31 & $<.05$ & & \\
& $\begin{array}{l}\text { Education } \\
\text { Organizational }\end{array}$ & .12 & 1.60 & $>.05$ & & \\
& $\begin{array}{l}\text { tenure } \\
\text { Perceived glass }\end{array}$ & .58 & 1.43 & $>.05$ & .45 & 24.04 \\
& ceiling & & & & & & \\
& & & & & & & \\
&
\end{tabular}

** Significant at $\mathrm{p}<.01 ; * \mathrm{p}<.05$

\section{Discussion and Conclusion}

The present study examined impact of personal attributes and perceived glass ceiling on organizational commitment of female employees and established that these factors influenced organizational commitment. The finding concurred with previous studies that reported these factors influence, and are associated with organizational commitment (Abdul Nasiru et al. 2014; Bombuwela \& Alwis, 2013; Downes et al., 2014; Macdonald \& Levy, 2016; Ng \& Feldman, 2010; Sabahattin et al., 2017; Salami, 2008).

Age had been reported to have a strong influence on organizational commitment as reported in past studies by Abdul-Nasiru et.al, (2014), Ogba 
(2008), and Salami (2008). This was further confirmed in the present study as age did show a strong influence on organizational commitment. However, the influence was negative and revealed that organizational commitment decreased as employees advanced in age. The outcome reflected that older employees may have reduced association with the organization's ideals and objectives, perhaps as a result of increasingly unfavourable experiences at work.

The influence of job position on organizational commitment as found in the present study was not significant. The finding showed that job position did not influence organizational commitment, and suggested that it did not contribute to it. This is not consistent with findings in past studies which established that organizational commitment increased among senior level employees ( $\mathrm{Ng} \&$ Feldman, 2010). But the finding in the present sample suggested that employees might have become ambivalent in their relationship with the organization and this may account for the lack of variation in their level of organizational commitment. The outcome may be expected among employees who may maintain membership with an organizational because the cost of leaving is perceived to be too high, especially in an economy just recovering from recession.

In this study, educational qualification did not predict organizational commitment, even though the result showed a weak but positive relationship between both variables. The result however confirmed previous findings that showed education had no significant influence on organizational commitment (Akinyemi, 2014; Zaitouni \& Sawalha, 2011). With public sector organizations failing to fulfil basic contractual obligations to their workers, the employees, irrespective of their educational status, may have lowered their initial work-related expectations which may have, in turn, affected the strength of their emotional attachment to the organization. The weak but positive relation between education and commitment implied that workers focused on the positive extrinsic rewards obtained through effort-bargain process without necessarily identifying with the organization's goals and values.

In confirming the importance of organizational tenure on organizational commitment, Meyer et al. (2002) did not support the current finding. It is not unlikely that commitment progressed from the early career stage when 
it is expected to be highly fluid, but then it eventually stabilized as the individual rose through the organizational hierarchy. At its peak, the individual perceived the self as a stakeholder in the success of the organization. But in the present study, tenure did not show significant influence on organizational commitment. Longer-serving employees may have been concerned about the uncertainty of not being compensated after their long stewardship. Studies that reported positive association may have been conducted in western societies that guarantee that employees are paid their entitlements, and timeously too.

With the highest contribution of $58 \%$, perceived glass ceiling was confirmed as the single most significant factor in organizational commitment. The finding did not support previous studies (e.g. Foley, 1998) who reported a negative influence of perceived glass ceiling on organizational commitment. But it supported findings that showed women were likely to retain organizational membership despite unfavourable work outcomes (Clark, 1997; Lumley, 2009). In explaining the finding in the present study, one might argue that it had to do with the inability of the sample to relate with the items in the questionnaires utilized for the research. The questionnaires were most likely developed in a setting that is culturally dissimilar to that of the respondents in the present study. The need for organizational behaviour scientists and practitioners to design culturally relevant, indigenous questionnaires for use locally is highlighted by this finding.

It can be concluded from the findings in the present study that perceived glass ceiling and age, more than other personal attributes are significant considerations that influenced organizational commitment. There are implications for managing female workers organizational commitment from these conclusions. First is that to reverse declining commitment, organizations should adopt HR practices that can elicit strong commitment from older workers because they are an important management tool - they help socialize younger employees to imbibe organizational values. Flexible working hours, reduced physical activity and work load should be considered as possibilities. Second, deliberate effort should be directed towards strengthening affective and normative aspects of commitment. HR practices that are emotionally motivating for female employees should be incorporated. 


\section{Onuoha \& Idemudia-Perceived Glass Ceiling \&Women Organization Commitment}

The design and sample were major limitations of this study. Specifically, the design of the study made it impossible to determine causality among the variables examined. Causal directions reported between variables are inferences because of the cross-sectional design adopted in the study. Even though the sample is diverse in specific ways (e.g., organization, job position, educational status and age), the role of individual differences could not be analysed because of gender homogeneity of the sample. Generalization of the outcome of the study may have been strengthened had respondents comprised a mixed gender sample as that would have allowed for comparative analysis of the result. These limitations notwithstanding, the study confirmed the importance of personal attributes, especially age and glass ceiling, in organizational commitment. Its contribution from a public sector perspective can influence workplace social policies that are especially relevant in today's organizations.

\section{References}

Abdul-Nasiru, I., Mensah, R., Amponsah-Tawiah, K., Simpeh, K. N., \& Kumasey, A. S. (2014). Organizational commitment in the public service of Ghana - An Empirical Study. Developing Country Studies, $4,1,49-55$.

Abrams, D., Swift, H. J., \& Drury, L. (2016). Old and unemployable? How age-based stereotypes affect willingness to hire job candidates. Journal of Social Issues, 72, 1, 105-121.

Adenguga, R. A., Adenuga, F. T., \& Ayodele, K. O. (2013). Organizational commitment and turnover intention among private universities employees in Ogun State. Nigeria Open Journal of Education, 1, 2, 31-36. doi: 10.12966/oje.05.04.2013

Affum-Osei, E., Acquaah, E., \& Acheampong, P. (2015). Relationship between organisational commitment and demographic variables: Evidence from a commercial bank in Ghana. European Journal of Research and Reflection in Educational Sciences, 769-778.

Akinyemi, B.O. (2014). Organizational commitment in Nigerian banks: The influence of age, tenure and education. Journal of Management and Sustainability, $4,4$. 
Allen, N.J. \& Meyer, J.P. (1990). The measurement and antecedents of affective, continuance, and normative commitment to the organization. The Journal of Occupational Psychology, 63, 1-18.

Ajayi, M.O. (2017). Influence of gender and age on organisational commitment among civil servants in South-West, Nigeria. Canadian Social Science, 13, 2, 29-35.

Aydin, A., Sarier, Y., \& Sengul, U. (2011). The effect of gender on organizational commitment of teachers: A meta-analytic analysis. Educational Sciences: Theory \& Practice, 11(2), 628-632

Bal, P. M., \& Kooji, D. (2011). The relations between work centrality, psychological job contracts, and job attitudes: The influence of age. European Journal of Work and Organizational Psychology, 20, 4, 497-523. doi: 10.1080/13594321003669079

Baumgartner, H., \& Steenkamp, J.B.E.M. (2001). Response styles in marketing research: A cross-national investigation. Journal of Marketing Research, 38, 143-156

Bayl-Smith, P. H., \& Griffin, B. (2014). Age discrimination in the workplace: Identifying as a late career worker and its relationship with engagement and intended retirement age. Journal of Applied Social Psychology, 44, 9, 588-599. doi: 10.1111/jasp.12251

Baxter, J. \& Wright, E. O. (2000). The glass ceiling hypothesis: A comparative study of the United States, Sweden, and Australia. Gender \& Society, 14, pp. 275-294

Becker, H.S. (1960). Notes on the concept of commitment. American Journal of Sociology, 66, 32-42.

Ben-Nwauzor, Ugo. (2016, April 23). Nigerian Women and the Political Glass Ceiling in Party Management. ThisDay Newspaper. Retrieved from http://www.thisdaylive.com/index.php/2016/04/23.

Boersch-Supan, A., Duezguen, I., Weiss, M. (2005). “Altern und Produktivität: Zum Stand der Forschung," MEA Discussion Paper 73-05.

Boon, O. K., \& Safa, M. S. (2006). TQM practices and affective commitment: A case of Malaysian semiconductor packaging organizations. International Journal of Management and Entrepreneurship, 2, 1, 37-55. 
1573 Onuoha \& Idemudia-Perceived Glass Ceiling \&Women Organization Commitment

Boswell, W.R. (2000). Aligning employees with the organization's strategic objectives: Out of "line of sight," out of mind. Unpublished doctoral dissertation, Cornell University

Chui, J., Tong, C., \& Mula, J. M. (2007). Assessing the extent to which career development impacts employee commitment: a case study of the ICT industry in Hong Kong. ACIS 2007 Proceedings. Retrieved from http://aisel.aisnet.org/acis2007/79

Clark, A.E. (1997). Job satisfaction and gender: why are women so happy at work?. Labour Economics, 4, 4, 341-372.

Dalgic, G. (2014). A meta-analysis: Exploring the effects of gender on organizational commitment of teachers. Issues in Educational Research, 24(2)

De Lange, A. H., de, Taris, T. W., Jansen, P. G. W., Smulders, P., Houtman, I. L. D., \& Kompier, M. A. J. (2006). Age as a factor in the relation between work and mental health: Results from the longitudinal TAS study. In J. Houdmont, \& S. McIntyre (Eds.). Occupational health psychology: European perspectives on research, education and practice, 1, pp. 21-45. Maia, Portugal: ISMAI.

Downes, M., Hemmasi, M., \& Eshghi, G. (2014). When a perceived glass ceiling impacts organizational commitment and turnover intent: The mediating role of distributive justice. Journal of Diversity Management, 9, 2,131-146. doi: 10.19030/jdm.v9i2.8971

Dubno, P., Costas, J., Cannon, H., Wankel, C. \& Emin, H. (1979). An empirically keyed scale for measuring managerial attitudes toward female executive. Psychology of Women Quarterly, 3, 4, 357-364

Duffy, R. D., Bott, E. M., Allan, B. A., Torrey, C. L.,\& Dik, B. J. (2012). Perceiving a calling, living a calling, and job satisfaction: Testing a moderated, multiple mediator model. Journal of Counseling Psychology. 59, 1, 50-9. PMID 22059426. doi:10.1037/a0026129

Everett, L., Thorne, D. \& Danehower, C. (1996). Cognitive moral development and attitudes toward women executives. Journal of Business Ethics, 15, 1227-1235.

Foley, S. (1998). The effects of the actual and perceived glass ceiling on perceptions of promotion fairness. Doctoral Dissertations. 


\section{AAI9906547.}

http://digitalcommons.uconn.edu/dissertations/AAI9906547

Gallie, D. \& White, M. (1993). Employee commitment and the skills revolution: First findings from the employment in Britain Survey, London, Policy Studies Institute. doi: 10.1177/014920630202800401 Glennie, A. (2012). “There's no such thing as a glass ceiling”. Dragon's Den star hits out at myth of rising to the top (Online) The Daily Mail. Available from http://www.dailymail.co.uk/news/article2194463/Dargon-den-star-Hilary-Devey-There-thing-glassceiling.html.

Keebler, D.W. (2012). Organizational commitment, job satisfaction, and turnover intention: A study of the baby boomer generation. Regent University, ProQuest Dissertations Publishing. 3532756

Kotzé, K., \& Roodt, G. (2005). Factors affecting the retention of managerial and specialist staff: An exploratory study of an employee commitment model. SA Journal of Human Resource Management, 3(2), 48-55. doi: 10.4102/sajhrm.v3i2.65

Krosnick, J.A. (1999). Survey Research. Annual Review of Psychology, 50, 537-567.

Kumasey, S. A., Eric Delle, E., \& Ofei, S. B. (2014). Occupational stress and organizational commitment: Does sex and managerial status matter? International Journal of Business and Social Research, 4(5), 173-182.

Kunze, F., Boehm, S. A., \& Bruch, H. (2011). Age diversity, age discrimination climate and performance consequences - A crossorganizational study. Journal of Organizational Behavior, 32, 2, 264-290. doi: 10.1002/job.698

Lumley, E.J. (2009). Exploring the relationship between career anchors, job satisfaction and organizational commitment. Unpublished Master's Dissertation. University of South Africa, Pretoria, South Africa.

Macdonald, J.L., \& Levy, S.R. (2016). Ageism in the workplace: The role of psychosocial factors in predicting job satisfaction, commitment and engagement. Journal of Social Issues, 72, 1, 169-190.

Madichie, N.O. (2009). Breaking the glass ceiling in Nigeria: A review of women's entrepreneurship. Journal of African Business, 10(1), 51-66, doi: 10.1080/15228910802701361 
1575 Onuoha \& Idemudia-Perceived Glass Ceiling \&Women Organization Commitment

Martin, A. \& Roodt, G. (2008). Perceptions of organizational commitment, job satisfaction and turnover intentions in a post-merger tertiary institution. SA Journal of Industrial Psychology, 34(1), 23-31.

Mathieu, J. E., \& Zajac, D. M. (1990). A review and meta-analysis of the antecedents, correlates, and consequences of organizational commitment. Psychological Bulletin, 108, 171-194. Retrieved from http://doi.apa.org/journals/bul/108/2/171.pdf

Mayer, R.C., \& Schoorman, F.D. (1992). Predicting participation and production outcomes though a two-dimensional model of organizational commitment. Academy of Management Journal, 35, 671-684

Meyer, J. P., Kam, C., Goldenberg, I. \& Bremner, N. L. (2013). Organizational commitment in the military: Application of a profile approach. Military Psychology, 25, 381-401.

Meyer, J. P., Stanley, D. J., Herscovitch, L., \& Topolnytsky, L. (2002).

Affective, continuance and normative commitment to the organization: A meta-analysis of antecedents, correlates, and consequences. Journal of Vocational Behavior, 61, 20-52. http://dx.doi.org/ 10.1006/jvbe.2001.1842.

Meyer, J.P. \& Allen, N.J. (1991). A three component conceptualization of organizational commitment. Human Resource Management Review. $1,1,61-89$.

Meyer, J.P., \& Allen, N.J. (1984). 'Testing the Side-Bet Theory' of organizational commitment: Some methodological considerations. Journal of Applied Psychology, 69, 3, 372-378.

Moorman, R.H., Niehoff, B.P., \& Organ, D.W. (1993). Treating employees fairly and organizational citizenship behavior: Sorting the effects of job satisfaction, organizational commitment, and procedural justice. Employee Responsibilities and Rights Journal, 6, 209-225

Mowday, R. T., Porter, L. W. \& Steers, R. (1982), EmployeeOrganizational Linkages: The psychology of commitment, absenteeism, and turnover. San Diego, CA: Academic Press.

Ng. T.H.W., \& Feldman, D.C. (2010). Organizational tenure and performance. Journal of Management, 36, 5, 1220-1250. 
Obeng, K. \& Ugboro, I.O. (2017). Post-tenure review, academic freedom, economic security and organizational commitment among college professors. ASBBS Proceedings; San Diego 24.1: 420-436. San Diego: American Society of Business and Behavioral Sciences, (Mar 2017).

Ogba, I. (2008). Commitment in the workplace: The impact of income and age on employee commitment in Nigerian banking sector.

Management Research News, 47, 11, 867-878. doi:

10.1108/01409170810913051

Ogunkoya, O.A., Elumah, L.O. \& Shobayo, P.B. (2013). Career stage effect on organizational commitment: A study of banks in Lagos State. International Journal of Business Management and Administration, 2, 9, 193-101.

Olodo M.A., Emunemu B.O. (2017). Push and Pull Factors in Women Attainment of Chief Executive Positions in South-West, Nigeria. In: Maringe F., Ojo E. (eds) Sustainable Transformation in African Higher Education. Sense Publishers, Rotterdam. doi: 10.1007/97894-6300-902-7_11

Ramamoorthy, N. \& Stringer, D. (2017). Equity versus equality norms of justice and organizational commitment: the moderating role of gender. Irish Journal of Management. doi: 10.1515/ijm-2017-0008

Redman, T., \& Snape, E. (2006). The consequences of perceived age discrimination amongst older police officers: Is social support a buffer? British Journal of Management, 17, 2, 167-175. doi: 10.1111/j.1467-8551.2006.00492.x

Rousseau, D.M. (1995). Psychological Contracts in Organizations. Thousand Oaks, CA: Sage

Sabahattin, T., Mehmet, T., Dilaver, T., \& Erdem, K. (2017). Effect of organizational trust, job satisfaction and individual variables on the organizational commitment in healthcare services. Total Quality Management \& Business Excellence, 28, 5-6.

Salami, O. S. (2008). Demographic and psychological factors predicting organizational commitment among industrial workers. Anthropologist, 10,1, 31-38.

Saleem, S., Rafiq, A., \& Yusaf, S. (2017). Investigating the glass ceiling phenomenon: an empirical study of glass ceiling's effects on 
1577 Onuoha \& Idemudia-Perceived Glass Ceiling \&Women Organization Commitment

selection - promotion and female effectiveness. South Asian Journal of Business Studies. doi: 10.1108/SAJBS-04-2016-0028

Sekaran, U. (2003). Research method for business: A skill building approach (4th edition). New York: John Wiley \& Sons.

Skirbekk, V. (2008). Age and productivity capacity: descriptions, causes and policy options. Ageing Horizons. 8, 4-12.

Strydom, H. (2002). Ethical aspects of research in the social sciences and human service professions. In A. S. de Vos, H. Strydom, C. B. Fouché, \& C. S. L. Delport (Eds.), Research at grass roots for the social sciences and human service professions (2nd ed., pp. 62-92). Pretoria: Van Schaik Publishers.

Tabachnick, B.G., \& Fidell, L.S. (2007). Using multivariate statistics $\left(5^{\text {th }}\right.$ edn). Boston: Pearson Education

The Center on Aging \& Work. (2011). Effects of country and age on work engagement, job satisfaction \& organizational commitment among employees in the United States.

Tolbert, P. S., \& Moen, P. (1998). Men's and women's definitions of "good jobs": Similarities and differences by age and across time. Work \& Occupations, 25, 168-194.

van Ours, J. (2009). Will you still need me: when I'm 64? De Economist. 157, 441-460.

Voloshin, G.V. (2016). Differences in organizational commitment between male and female coaches at the high school level. Education Doctoral. Paper 270.

Yew, L. T. (2008). Job Satisfaction and affective commitment: A study of employees in the tourism industry in Sarawak, Malaysia. World Review of Entrepreneurship, Management and Sustainable Development, 4(1), 85-101.doi: 10.1504/WREMSD.2008.016210

Zaitouni, M., \& Sawalha, N. N. (2011). The impact of human resource management practices on organizational commitment in the banking sector in Kuwait. International Journal of Business and Management, 6(5), 108-123. doi: 10.5539/ijbm.v6n6p108 
GÉNEROS -Multidisciplinary Journal of Gender Studies, 7(1) 1578

Chibuzor Uchenna Onuoha, doctor

Erhabor Sunday Idemudia, doctor

Contact address:

North West University,

Mafikeng Campus,

South Africa

E-mail address:

chibuzor.onuoha@nwu.ac.za, erhabor.idemudia@nwu.ac.za 